Інноватика у вихованні. Випуск 11. Том 1. 2020.

УДК 37(477)(092)

DOI: $10.35619 /$ iiu.v1i11.279

Сухомлинська Ольга

доктор педагогічних наук, професор,

дійсний член НАПН України, головний науковий співробітник ДНПБ України імені В. Сухомлинського,

м. Київ, Україна

ORCID: 0000-0002-2033-285X

e-mail:2991946@gmail.com

\title{
ВАСИЛЬ СУХОМЛИНСЬКИЙ КРІЗЬ ПРИЗМУ ЧАСУ: ДЕЯКІ ЗАУВАГИ ДО РОЗГЛЯДУ ІДЕЙ
}

\begin{abstract}
Анотація. У статті представлений погляд на спадщину Василя Сухомлинського 3 двох позицій - як історичного надбання, приділяючи першочергову увагу першоджерелам, а не інтерпретаційним працям, відцензурованим текстам або ж збіркам уривків 3 праць, а також як на доробок, який і нині може підживлювати освітньо-виховну практику. Виявлено недостатнє або ж поверхове вивчення джерельної бази, яке часто підмінюється творами, що вийшли після смерті автора з відредагованими правками.

У статті схарактеризовані й розкриті ті напрями творчого доробку, які мають актуальне звучання, але не знайшли відповідного розкриття як в історикопедагогічних дослідженнях, так і в загальнопедагогічній проблематиці. До них авторка зараховує: необхідність поєднання, а не відокремлення теорії і практики як 3 боку науковців, так і з боку учительства; думки педагога про організацію i проведення пошуково-експериментальної роботи в школі як довготривалого i виваженого процесу - від підготовчого етапу до незвичного тривалого експериментування; думки педагога про безпосередню участь учнів в організації власного шкільного і навколишнього середовища; погляди педагога на організацію і проведення індивідуальної роботи з важкими дітьми (інклюзія); аналіз його думок про «олюднення» знань; важливість емоційно-ціннісного супроводу світоглядних орієнтирів освіти тощо. Обраний підхід розширює наше розуміння спадщини педагога, а підняті у статті питання збагачують і поглиблюють усвідомлення тих кардинальних змін, що відбуваються нині в українській освіті, які викликані, серед іншого, й історичними чинниками й передумовами.
\end{abstract}

Ключові слова: Василь Сухомлинський, педагог, спадщина, актуальність, школа, освіта, експериментування, керівництво, діти, гуманізм, інклюзія, середовище, розвиток, ідеї, реформування.

Постановка проблеми. Думки та ідеї, висловлені відомими педагогами віддаленого і недавнього минулого, з плином часу не втрачають своєї цінності і повертаються до дослідницького поля у часи, коли освітяни шукають шляхи подальшого розвитку педагогічної теорії і практики. Це особливо стосується такої постаті як Василь Сухомлинський, столітній ювілей якого в 2018 році широко відзначався не лише в Україні, а й у світі на рівні ЮНЕСКО. Ювілейна дата привернула велику увагу до спадщини педагога, вона аналізувалася науковцями, до неї зверталися педагоги-практики. 3'явилося досить багато публікацій, присвячених різним аспектам його творчого доробку. Тому сьогодні, з плином часу, викристалізувалася потреба оцінити ці публікації, виявити нерозкриті й 
непрояснені питання, які залишилися поза увагою дослідників, але все ж потребують висвітлення.

Аналіз останніх досліджень 3 проблеми. Упродовж багатьох років дослідження спадщини В. Сухомлинського досить репрезентативно представлені у вітчизняному дослідницькому просторі. Підготовлено i захищено багато дисертаційних досліджень, опубліковано монографічні роботи. Але, виходячи 3 поставленої нами проблеми, об'єктом аналізу виступлять дослідження останніх двох років. Це два випуски Наукових записок Центральноукраїнського державного педагогічного університету імені В. Винниченка, серія «Педагогічні науки», що вийшли у 2018 р. (№ 171 - 237 с. і № 172 - 257 с.), які повністю були присвячені різним аспектам педагогічної спадщини Сухомлинського. На сторінках цих часописів виступила велика кількість провідних науковців України і зарубіжжя 3 аналізом окремих напрямів спадщини педагога, розмислами щодо їх затребуваності й важливості для сьогодення. I серед них: про модернізацію сучасної початкової освіти крізь призму ідей педагога (О. Савченко, Я. Кодлюк та ін.), про підготовку майбутнього учителя у діалозі із В. Сухомлинським (Н. Кічук, Н Калениченко, С. Мельничук, Л. Хомич), про важливість патріотичного виховання (А. Богуш, В. Кузьменко, П. Олешко), про роль і значення казки для сучасної початкової освіти (І. Баранюк, Ю. Кузьменко, Т. Тоцька, Т. Янченко) та інші.

Нами були проаналізовані також збірник наукових праць Рівненського державного гуманітарного університету (вип.10, 2019р.) та часопис «Нова педагогічна думка» (№3 (99), 2019p.) - видання Рівненського обласного інституту післядипломної педагогічної освіти, які в цілому присвячені методичним аспектам педагогічної спадщини В. Сухомлинського. Здійснений аналіз виявив, що певні питання залишилися поза увагою дослідників i не були достатнім чином проаналізовані.

Метою написання цієї розвідки є висвітлення тем і сюжетів стосовно творчого доробку В. Сухомлинського, які потребують вивчення і розгляду як з позицій історико-педагогічної науки, так і доповнення та додаткового аргументування задля розв'язання актуальних питань сучасної освіти.

Виклад основного матеріалу дослідження. У 2018 році виповнилося 100 років від дня народження Василя Сухомлинського і 48, як він пішов 3 життя. Педагог залишив, як знаємо, велику творчу спадщину, яка впродовж цих десятиліть поповнювалася виданнями творів, які не були опубліковані за його життя, тематичними збірками, літературою для дітей (Сухомлинська, Березівська та Страйгородська, 2018 a). У своїй сукупності вона виступала предметом досліджень різних за статусом i кваліфікацією науковців i практиків (Сухомлинська, Березівська та Страйгородська, 2018 b). Чи є ця спадщина, як і сам Сухомлинський, історією, перегорнутою сторінкою нашого життя? Чи, натомість, можемо віднайти щось цікаве в його творах, що може і сьогодні здивувати, вразити, показати звичне під іншим кутом зору, підказати нові ідеї?

Як видається, і те, й інше, і намагатимемося зупинитися на моментах, які, або зовсім не були розкриті під час Року Сухомлинського, або подавалися дещо під іншим ракурсом.

Перш за все задамося питанням: а чи знаємо творчий спадок Сухомлинського, не дивлячись на те, що він досліджувався і продовжує досліджуватися багатьма? Вважаємо, що в деяких своїх аспектах він майже не вивчений, оскільки рідко хто звертається до прижиттєвих видань, найчастіше - до п'ятитомного видання творів, опублікованого в 1976-1977 роках (Сухомлинський, 1976-1977) (російською 
мовою - 1979-1980 рр.), яке, на нашу думку, є класичним прикладом радянського підходу до упорядкування, відбору й оприлюднення текстів. Частина поміщених у п’ятитомнику праць Сухомлинського була вже відцензурована, коли друкувалася вперше за життя педагога (Сухомлинський, 2018), але у зазначеному виданні всі без винятку тексти підлягали цензуруванню. Одні, як виявляється, піддавалися подвійній цензурі, ті ж, що публікувалися вперше, рецензувалися відповідно до ідеологічних і педагогічних вимог кінця 1970-х років. П'ятитомне видання як українською, так i російською мовами віддзеркалює радянську практику урегульованого, цензурованого коригування текстів відповідно до світоглядних, ідеологічних, політичних доктринальних уявлень і канонів, складає «радянську картину світу» (Червинский, 2011) і може, на нашу думку, виступати джерелом лише з відповідним аналізом і коментуванням.

Окрема тема - тематичні збірки, підготовлені різними упорядниками, як-от: «О воспитании» (С. Соловейчик) (1973), «Батьківська педагогіка» (В. Ф. Шморгун) (1978), «Родина в сердце» (Г. І. Сухомлинська, Л. В. Голованов) (1978), «Родительская педагогика» (без упорядника) (1978), «Потребность человека в человеке» (Т. В. Самсонова) (1978) та ін. Вони, як правило, сучасними авторами розвідок про різні аспекти спадщини педагога класифікуються як оригінальні твори Сухомлинського, що також свідчить про поверховість їхніх досліджень. Ними не береться до уваги, що упорядники відбирають твори і уривки з текстів відповідно до власних уподобань та власних педагогічних позицій. Щодо архівних матеріалів, то вони, як правило, не виступають предметом дослідження. I Рік Сухомлинського нам нічого в цьому напрямі не запропонував і не додав. А такий підхід - і звернення до першоджерел - уможливив би більш повний і глибокий аналіз творчості педагога.

Інший аспект досліджень - розгляд персоналії на тлі, у контексті доби. Хоча ми часто зловживаємо цими виразами, застосовуємо їх навіть тоді, коли цей контекст представлений мінімально, або ж його зовсім немає. Для дослідників аксіоматичною є теза про те, що постаті минулого не можна розглядати відірвано від контексту, поза системою зв'язків і взаємозалежностей. I, звичайно, Сухомлинський - це син свого часу, 60-х років XX століття, першої радянської відлиги, представник шестидесятників. Радянська цивілізація в ці роки висунула серед інших відомих діячів культури і Сухомлинського. Він був разом з тими, хто підіймав такі питання: що являє собою людина; яка мета іiі життя; у чому іiі призначення; що таке моральність, духовність, тобто, що таке добро і що таке зло. Ці питання пов'язані з часом, у якому живе людина і разом з тим не мають часового виміру і з кожним новим поколінням, новими викликами знову й знову постають перед суспільством і кожною окремою людиною. Василь Олександрович як учитель, директор школи, як дослідник завжди приділяв їм велику увагу, але особливо в ті роки, коли вони підіймалися в багатьох сферах - філософії, психології, літературі, мистецтві. Він же розмірковував над феноменом дитинства: як потрібно навчати і виховувати дітей, щоб вони розуміли сенс життя, свого i оточуючих; як через освіту і виховання донести до дитини морально-етичні ідеї, норми та правила, прищепити культуру, показати належність до свого роду i народу.

Його великою перевагою і важливим аргументом для розроблення цих ідей було те, що він упродовж 22 років очолював загальноосвітню середню школу. Саме вона стала експериментальним майданчиком для висунення, перевірки та впровадження нових ідей, дала можливість не тільки створити свій власний образ і модель школи, іï філософію, а також запропонувала величезну кількість матеріалу 
для написання й обнародування 45 книг та більш, ніж 500 статей науковопубліцистичного змісту. Як видається, ця константа, цей інваріант - зв'язок $з$ практикою, живим життям учителів і дітей, щоденне не лише спостереження, а й безпосередня участь у педагогічному процесі, залишаються актуальними й нині. Більше того, вони виступають загальною педагогічною закономірністю. Нині ж часто-густо спостерігаємо певний «розподіл праці» у педагогів. $Є$ теоретики, які спеціалізуються виключно на теорії, розробці теоретичних питань, $\epsilon$ й практики, які мають застосовувати ці ідеї, впроваджувати їх у практику.

Розмірковуючи над цим явищем, Сухомлинський вважав, що «у самій своїй основі педагогічна праця - справжня творча праця - стоїть близько до наукового дослідження». «Ця близькість, спорідненість, - уточнює педагог, - полягає передусім в аналізі фактів і необхідності передбачення. I цією першою сходинкою якраз і є аналіз педагогічних явищ у власній роботі» (Сухомлинський, 1988, с.9899). Тобто, не відокремленість, а поєднання - ось плідний і конструктивний шлях до успіху у навчанні дитини. При цьому Сухомлинський вважав, що дослідницька робота вчителя, як і науковця, має носити довготривалий, а не короткостроковий характер. Ця теза і в його часи викликала критику, а нині ми перейшли до прискореного вирішення всіх освітніх проблем, наче знаходимося у експрес-потязі, що мчить без зупинок.

Ставлячи перед собою і колективом завдання, Василь Олександрович зазначав, що «попереду (була - О.С.) довготривала, постійна робота, результати якої залежали від найрізноманітніших чинників навчально-виховного процесу: від підвищення загальної і педагогічної культури педагогів, від правильної постановки методичної роботи, від збагачення матеріальної бази та інших» (Сухомлинський, 1958, с.79). У книзі «Павлиська середня школа» (1969) педагог наводив приклад тривалого дослідження, над яким працював колектив, - це «єдність думки і почуття», мови і мислення.

Принагідно наголосимо, що Сухомлинський наполягав і на довготривалості виховної дії, виховного впливу на особистість, вважаючи це закономірністю педагогічного процесу («тривалість - найважливіше у виховній роботі» (Обговорення книги В. О. Сухомлинського «Формирование коммунистических убеждений у молодого поколения» (1962)). Зараз про довготривалість взагалі не йдеться, особливо в кандидатських і докторських дисертаціях, які за два-три роки написання роботи досягають таких «успіхів» у вихованні, які й не снилися учителям-практикам і Сухомлинському також.

Отже, одна з необхідних умов педагогічної праці - це створення педагогічного колективу, який не тільки може, але й, що найголовніше, хоче бути творчим, креативним. Ця умова також $є$ актуальною сьогодні. Сухомлинський дуже багато уваги приділяв учительському колективу, вивчав кожного вчителя, досконало знав його життєві обставини і проблеми, моральні якості, духовні потреби та інтереси. Для кожного він знаходив добре слово, але й умів робити зауваження, а це набагато складніше, ніж хвалити. І тут ми бачимо, як індивідуальний і гуманістичний підхід, 3 яким він ввійшов у педагогічну науку, був застосовуваний перш за все його колегами-учителями.

Я не поділяю думку відомого російського журналіста Валерія Хілтунена про те, що Сухомлинський був зовсім незрозумілим ні дітям, ні своїм педагогам («3 чого їм було його зрозуміти, нащадкам рабів і онукам скотарів...») (Хилтунен, 1988), але важко заперечити, що він був керівником яскраво вираженого лідерського типу. Ось як про це писав постійний кореспондент Сухомлинського, неодноразовий відвідувач Павлиша, вірменський педагог і культуролог Рафаель Атаян: «На всій 
багатогранності культурно-виховних заходів у Павлиській школі постійно відчувався незгладимий відбиток незвичайної особистості директора школи. У всіх починаннях такого роду незримо був присутній Василь Олександрович Сухомлинський з його широким світоглядом, ненаситним інтересом до досягнень науки, мистецтва, літератури, романтичним устремлінням і глибокою вірою в людину» (Атаян, 1990). Про це переконливо свідчать і робочі матеріали діяльності школи (протоколи педагогічних рад, психологічних семінарів, розклад занять школи для батьків тощо), де весь час зустрічаємо переважно прізвище Сухомлинського.

Вивчення того, як це здійснював педагог, могло б і нині стати в нагоді і директорам закладів середньої освіти, і керівникам інших установ та організацій. Але, екстраполюючи ідею про необхідність і важливість проведення педагогами великої не лише додаткової, а й творчої роботи на нинішні реалії, ми дійшли висновку, що Сухомлинському легше було діяти в тодішніх умовах адміністрування школи, директивної шкільної політики, було більше важелів проводити дослідницьку роботу, доносити до вчителя важливість і необхідність новаторських ідей, які великою мірою здійснювалися під час ненормованої, додаткової роботи.

Нині ж бажання творити виступає головною внутрішньою спонукою вчителя, директора, і в учасників перш за все постає питання про оплату додаткового навантаження, додаткового витрачання часу. Постає проблема зацікавлення не лише дітей, а й учителів у пошуковій і дослідницькій роботі.

Наступна теза. Сухомлинський увійшов в історію як педагог, головним принципом діяльності якого став гуманізм. Гуманізм був відомим педагогіці багатьох цивілізацій, але в радянській освіті ця ідея була висловлена вперше стосовно кожної без винятку дитини: полюби, поважай, не завдай шкоди, допоможи, підтримай, збережи... - ось чим опікується Василь Олександрович, радикально змінюючи акценти і наповнюючи новим змістом моральні, розумові, трудові, естетичні, ідейно-патріотичні складові радянського виховання, орієнтованого передусім на партійно-ідеологічні й соціалізаційні впливи. Наприклад, Василь Олександрович у відповідь на один 3 листів писав: «Особистість формується все ж таки особистістю, а не «багатогранною діяльністю суспільства», як ви пишете. Стосовно дитини - це дзвінка фраза, пуста риторика. ... Ідеї впливають на людей не самі по собі, а через тих же людей. Ідеї ходять по землі у людській подобі...» (Сухомлинський, 1970 а).

Через особистісну взаємодію між дорослим і дитиною, учителем і учнем Сухомлинський бачив шлях до наближення педагогічної теорії і практики до психічних, розумових потреб усіх без винятку дітей, розвитку їхніх здібностей, приділення уваги кожній дитині - таким було педагогічне кредо Сухомлинського, основа для розвитку гуманності.

Положення, що дитина - центр педагогічної системи, що саме на ній акумулюється весь педагогічний процес, $\epsilon$ основоположним i в педагогічних працях, і в організації освітньо-виховного процесу, яке конкретизується в особистісно орієнтованому навчанні, індивідуальному та диференційованому підходах. Сьогодні ми пов'язуємо ці підходи з Новою українською школою, ії концептуальним і змістовим наповненням, а передовсім з інклюзивною освітою.

Питанням «Сухомлинський і важкі діти», «Сухомлинський і інклюзія» було приділено досить багато уваги впродовж Року Сухомлинського. I це далеко не випадково, оскільки важке дитинство, діти з особливими потребами сьогодні $\epsilon$ не менш гострим питанням, можливо, навіть більш гострим, ніж за часів 
Сухомлинського, що пояснюється нестабільністю, плинністю процесів життя, погіршенням екологічної, соціально-економічної ситуації, демографічною кризою.

Педагог був переконаний, що навчання таких дітей - це особливий іспит на людяність для всіх: дітей, учителів, батьків, громади. В останньому Плані роботи школи на 1970/1971 навчальний рік, підготовленим Сухомлинським, читаємо: «Окремим питанням, над яким працює протягом багатьох років директор школи, $\epsilon$ розвиток розумових здібностей у розумово відсталих, малоздібних, повільно думаючих дітей» (Сухомлинський, 1970 b). Таким дітям надавали індивідуальну допомогу і на уроках, і в позаурочний час, і в сім'ї, «розуміючи, - писав Василь Олександрович, - що ніякими зусиллями від важкого учня не доб'єшся таких самих знань, як від інших дітей, учитель звикає вимірювати його успіхи особливими мірками: для кожної важкої дитини - своя мірка... Від успіху до успіху - в цьому складається розумове виховання важкої дитини» (Сухомлинський, 1988, с. 144145).

І лише початок величезної, складної і в цілому ризикованої (бо маємо справу 3 життям і долею вразливих в соціальному плані дітей) роботи. На цьому шляху вже зустрічаємо труднощі і перешкоди, які, якщо їх не подолати або ж не звертати на них уваги, можуть знівелювати й знецінити гуманну ідею. Ось, наприклад, про що говорить в інтерв’ю газеті «Дзеркало тижня» одна з громадських діячок, яка сама $\epsilon$ слабозорою: «3 одного боку, я хочу вірити, що державна політика щодо інклюзії, толерантності призведе до гарних результатів і все буде добре. 3 іншого боку, я бачу сліпих дітей, яких два роки тому забрали із спеціалізованої школи в інклюзивну, тому що мама надихнулася, а потім дитина перестала ходити в ту інклюзивну школу і майже два роки просиділа вдома. Перш за все, до інклюзї має бути готовим суспільство. Все має бути зроблено поступово і не так» (Онищенко, 2018).

Звичайно, на початку шляху трапляються різні труднощі. Але нині, розкриваючи сутність підходу Василя Олександровича до питань важкого дитинства, доцільно перш за все акцентувати увагу на його ідеях щодо поступовості, довготривалості цього процесу, підготовки учителя і батьків до присутності таких дітей у класі, підготовки відповідних педагогічних кадрів, гуманізації суспільної думки й налагодження співпраці різних учасників.

Наступна теза стосується підходу до навчання як до олюднення знань через переживання й осмислення сутності людського життя, тобто такий зміст освіти, де головною виступає людина, іiї потреби і діяльність. Іншими словами, навчати в тісному взаємозв'язку з потребами і людини, суспільства і найближчого оточення: «Виховання середовищем, оточенням, створеним самими учнями, речами, які збагачують духовне життя колективу, це, на наш погляд, одна 3 найтонших сфер педагогічного процесу, - писав він. - Матеріальну базу школи ми розглядаємо в нерозривній єдності з оточенням, до якого входить природа, праця і громадська діяльність оточуючих людей» (Сухомлинський, 1969, с106).

Ці думки Сухомлинського сприймаємо сьогодні як діяльність школи як відкритої системи. 3 одного боку, школа виступає невід'ємною складовою соціуму, навколишнього середовища, а з іншого - вона сама його створює, виступає організаційним і методичним його центром, і тоді іiі функції не обмежені раз і назавжди встановленими правилами, вказівками, приписами, а весь час видозмінюються.

3 думок Сухомлинського, наведених вище, нині з нашої уваги зникає важливе, як на мене, положення про те, що діти, учні самі виступають творцями свого середовища. Сьогодні переважає тенденція, що школу потрібно устаткувати: 
привезти відповідні меблі, картини, картинки, іграшки, наочність і дати все це дітям у готовому вигляді, розкласти все це, щоб дитина бачила. У сучасному розумінні це і $є$ навчальне середовище школи. (До речі, дуже дивує облаштування деяких класних кімнат, особливо початкової ланки, де практично немає вільного місця від яскравої, різноспрямованої наочності. А як же бути з увагою дітей, 3 необхідністю зосередитися на певній темі? Що 3 цього приводу говорять психологи?).

У школі Сухомлинського шкільне середовище не лише вибудовувалося під дитину, а й самою дитиною, щоб схвилювалося серце учня, збагатилася його думка, виникло бажання зробити світ навколо себе кращим. У школі багато що було зроблено руками дітей, і Сухомлинський намагався, щоб кожен вклав у створення шкільного середовища не лише працю, а й частинку свого серця. Звичайно, в таких школах одразу видно, що все це зробили самі діти, щиро, але не завжди вправно. Тому, за часів Сухомлинського багато хто вважав його школу «бідненькою», «примітивною», але цей «примітив» був зроблений, написаний і намальований руками самих дітей і вчителів, зроблений з душею, повішений на стіну, бо то хвилювало дитину, відповідало іiі почуттям і настроям. Саме такий підхід зустрічаємо в школі Селестена Френе, в інтернаті Януша Корчака, інших авторських школах, де дитина за допомогою дорослого розбудовує свій простір, своє життя. Там було не доросле розуміння дитячого життя, дитинства загалом, а продумане педагогами середовище, облаштоване самою дитиною. Вважаю, що саме така школа була у Сухомлинського в Павлиші - на рівні кращих світових тенденцій, а не найбагатших. Багатство було в душі, книжці, малюнку, музиці, любові, дружбі, природі, учителеві, в самому Сухомлинському.

I ще на одному аспекті педагогіки Сухомлинського хотілося б коротко зупинитися - ідейна, ідеологічна складова його творів, яку сьогодні або зовсім не згадують, або говорять як про невід'ємний і негативний атрибут, що свідчить про його належність до радянської цивілізації, ії провідних ідеологем. Викладу своє розуміння цієї складової творчого спадку педагога. Коли звернутися до концептуальних засад його міркувань, то виявимо, що ідейна, світоглядна освіта і виховання у Сухомлинського - це серцевина виховного процесу, структурована в систему освіти, яка носить ідеалізований характер; це спрямований у майбутнє сплав громадянськості і людяності, що у нього має виключно особистісний характер. Таким чином, суспільно значущі ідеали були представлені Сухомлинським як особистісні, виходили із внутрішнього світу дитини, і головне - були пов'язані з діяльністю, з емоційно-ціннісним супроводом ичієї діяльності, тобто рівнем домагань учня, його самоідентифікацією та самоствердженням.

Це важливе положення, яке розкриває смисл і мету діяльності всієї освітньої системи. Нині ж в нашій школі іноді спостерігаємо, як відсутність такої спрямованості шкільного життя, шкільного змісту освіти призводить загальну середню освіту до сукупності викладання окремих предметів.

Ми вже зазначали, що Сухомлинський відстоював ідею про олюднення змісту освіти через долучення до ідеалів, ідей і цінностей, говорив про «одухотвореність» через пізнання світу. «Не лише розумом, але й серцем», - ось педагогічне кредо, яке втілювалося і на уроках, і на лекціях, і більшою частиною в діяльності, внеску кожної дитини в загальну справу. Наблизивши суспільний ідеал до сфери особистого життя кожного учня, Сухомлинський переконував, що таке виховання має носити особливо тонкий характер. Він неодноразово підкреслював небезпеку вкладання у вуста дитини того, чого вона не може осягнути і пережити: «Більше, ніж хтось інший, ми (вчителі - О.С.) бачимо страшну небезпеку дзвінкої фрази, 
демагогічної балаканини, пустопорожніх обіцянок у вустах дітей і юнаків... Дзвенять красиві слова, але для дітей вони порожні, бо складені й придумані дорослими, діти їх не розуміють і не відчувають. Дорослий лицемір небезпечний, лицемір-дитина - страшна - вона наше творіння, ми покалічили її душу, привчили користуватися дорогими високими словами як розмінною монетою. Не робіть цього, товариші! Не вкладайте в дитячі вуста таких слів, для яких немає реальної основи в юному серці - переживань, які виросли 3 живих людських відносин» (Сухомлинський, 1977). Ці слова відразу ж приходять на думку, коли й нині чуємо на різних заходах виступи дітей, які повторюють вкладені дорослими слова, щодо яких у них немає ні власних думок, ні уявлень, ні переконань.

Разом $з$ тим Сухомлинський критично оцінював зміни в освіті, i, можливо, й не було в Радянському Союзі критика системи освіти більшого, ніж Сухомлинський. Про це вперше написала німецька дослідниця Еріка Гартманн (2010). Педагог брав активну участь у публічних обговореннях процесів реформування освіти, критично відгукувався на деякі нововведення, вважав, що школа не повинна підлягати постійній перебудові, особливо, якщо в цих процесах $є$ неясність, непевність (Сухомлинський, 1988a, Сухомлинський, 1988b).

Цікаво, що сказав би Сухомлинський щодо сучасних безкінечних реформаційних процесів. Переконана, що це мало йому сподобалося б.

Висновки i перспективи подальших розвідок. Відтак, на прикладі Сухомлинського спостерігаємо, що проблеми розвитку особистості, гуманізму, моральності, духовності не зникають з педагогічного поля, а набувають все більшої ваги. I тут можемо прослідкувати, що позиція Сухомлинського, його ідеї з часом не втратили своєї актуальності, а посіли, звичайно, у видозміненому і розвинутому вигляді провідні позиції в педагогічній науці і практиці. Тому так важливо звернутися до витоків і першоджерел як до історичних коренів сучасності, виявити подібні ситуації в минулому i, проаналізувавши їх, долучити до вирішення важливих педагогічних проблем.

Аналіз розглянутих проблем підводить нас до питань: чи стануть розглянуті ідеї повністю історичним надбанням? Чи можемо використати їх нині і на майбутнє у будь-який підходящий для нас спосіб? Це дуже складне питання, адже нинішні цивілізаційні здобутки разом з викликами і загрозами носять такий масштаб, який, вірогідно, вимагатиме зовсім нових підходів і рішень, але які, безперечно, повинні виключати наукове осмислення нашого минулого.

\section{СПИСОК ВИКОРИСТАНИХ ДЖЕРЕЛ}

Сухомлинська, О., Березівська, Л. та Страйгородська, Л. (2018 а). Василь Олександрович Сухомлинський: до 100-річчя від дня народження. Біобібліографічний покажчик. Вінниця. Твори. 395 с.

Сухомлинська, О., Березівська, Л. та Страйгородська, Л. (2018b). Вивчення діяльності i творче використання спадщини В. Сухомлинського Василь Олександрович Сухомлинський: до 100-річчя від дня народження. Біобібліографічний покажчик. Вінниця. Твори. 395 с.

Сухомлинський, В. (1976-1977). Вибрані твори: В 5 m. Київ: Рад. школа.

Сухомлинський, В. (2018). Редакційні стратегії. Серце віддаю дітям. Харків: Акта. С.482-528.

Червинский, Петр. (2011). Негативно оценочные лексемы языка советской действительности. Обозначение лии. Томск: Изд. «КИТ». 341c.

Сухомлинський, В. (1988). Розмова з молодим директором. Київ: Рад. школа. $284 \mathrm{c}$. 
Сухомлинский, В. (1958). Педагогический колектив средней школьл. Москва: Просвещение. 207 с.

Обговорення книги В. О. Сухомлинського «Формирование коммунистических убеждений у молодого поколения» (1962). Советская педагогика. № 6. С. 156-160.

Хилтунену, В. (1988). Письма из Павлыша : [письма от 22 февр. 1970 г.; 20 марта 1970 г.; 17 апр.1970 г.; 18 мая 1970 г.]. Комсом. правда. 28 сент.

Атаян, Р. (1990). В. О. Сухомлинський, яким я його знав. Спогади про Сухомлинського. Київ: Рад. шк. С.163.

Сухомлинський, В. (1970 а). Лист-відповідь Сухомлинського Олександру Івановичу (без прізвища - О.С.) з приводу публікації його статті «Слово до батьків» (Правда. 1970. 5 січня). Особистий архів родини Сухомлинських.

Сухомлинський, В. (1970b). План роботи Павлиської середньої иколи на 19701971 навчальний рік. ЦДАВО України. Фонд 5097. Опис 1. Справа 930. 108 с.

Онищенко, О. (2018). До інклюзії має бути готовим суспільство. Дзеркало душі. № 42-43. URL: https://dt.ua/personalities/do-inklyuziyi-maye-buti-gotovim-suspilstvo293603_html [дата звернення 26.04.2020].

Сухомлинский, В. (1969). Павльшская средняя школа. Москва: Просвещение. $400 \mathrm{c}$.

Сухомлинський, В. (1977). Народний учитель. Вибрані твори. В 5 томах. Т.5. Київ: Рад. школа. с.251.

Гартманн, Е. (2010). В. О. Сухомлинський: критик радянської та капіталістичної системи: новий погляд на спадщину класика педагогіки. Шлях освіти. №1. С.32-37.

Сухомлинский, В. (1988 а). К вопросу об организации школ-интернатов (написано 17 серпня 1956 р.). Сов. педагогика. № 12. С.82-88.

Сухомлинский, В. (1988 b). Письмо Н.С. Хрущееву [з приводу питань, піднятих Н.С. Хрущовим у Доповідній записці до Президії ЦК КПРС, щодо реформування системи освіти в СРСР, написане і відправлене 12 червня 1959 р.]. Сов. педагогика. № 3. С. 97-102.

\section{REFERENCES}

Sukhomlynska, O., Berezivska, L. ta Straihorodska, L. (2018 a). Vasyl Oleksandrovych Sukhomlynskyi: do 100-richchia vid dnia narodzhennia [Vasyl Oleksandrovych Sukhomlynsky: to the 100th Anniversary of His Birth] Biobibliohrafichnyi pokazhchyk. Vinnytsia. Tvory. 395 s. (in Ukrainian)

Sukhomlynska, O., Berezivska, L. ta Straihorodska, L. (2018 b). Vyvchennia diialnosti $i$ tvorche vykorystannia spadshchyny $V$. Sukhomlynskoho [Study of V. Sukhomlynsky's Activity and Creative Use of His Heritage]. Vasyl Oleksandrovych Sukhomlynskyi: do 100-richchia vid dnia narodzhennia. Biobibliohrafichnyi pokazhchyk. Vinnytsia. Tvory. 395 s. (in Ukrainian)

Sukhomlynskyi, V. (1976-1977). Vybrani tvory: V 5 t. [Selected Works: in 5 Vol.]. Kyiv: Rad. shkola. (in Ukrainian)

Sukhomlynskyi, V. (2018). Redaktsiini stratehii. Sertse viddaiu ditiam [Editorial Strategies. I Give My Heart to Children]. Kharkiv: Akta, S.482-528. (in Ukrainian)

Chervinskii, Petr. (2011). Negativno otsenochnye leksemy iazyka sovetskoi deistvitelnosti. Oboznachenie lits. [Negatively Estimated Lexemes of the Language of Soviet Reality. Face Designation]. Tomsk: Izd. "KIT". 341s. (in Russian)

Sukhomlynskyi, V. (1988). Rozmova z molodym dyrektorom [Conversation with a Young Director]. Kyiv: Rad. shkola. 284 s. (in Ukrainian) 
Sukhomlinskii, V. (1958). Pedagogicheskii kolektiv srednei shkoly [Pedagogical Staff of Secondary School]. Moskva: Prosveshchenie. 207 s. (in Russian)

Obgovorennia knigi V. O. Sukhomlinskogo "Formirovanie kommunisticheskikh ubezhdenii u molodogo pokoleniia" [Discussion of V. O. Sukhomlinskii's book "Formation of Communist Beliefs among the Young Generation"] (1962). Sovetskaia pedagogika. No 6. S. 156-160. (in Russian)

Khiltunenu, V. (1988). Pisma iz Pavlysha [Letters from Pavlysh]: [pisma ot 22 fevr. 1970 g.; 20 marta 1970 g.; 17 apr.1970 g.; 18 maia 1970 g.]. Komsom. pravda. 28 sent. (in Russian)

Ataian, R. (1990). V. O. Sukhomlynskyi, yakym ya yogo znav. Spogady pro Sukhomlynskoho. [V.O. Sukhomlinskyi, as I Knew Him. Memories of Sukhomlinskyi]. Kyiv: Rad. shk. S.163. (in Russian)

Sukhmlynskyi, V. (1970 a). Lyst-vidpovid Sukhomlynskoho Oleksandru Ivanovychu (bez prizvyshcha - O.S.) z pryvodu publikatsii yoho statti "Slovo do batkiv" [Sukhomlynskyi's Letter to Oleksandr Ivanovych (without surname - O.S.) on the Occasion of the Publication of His Article "A Word to Parents"] (Pravda. 1970. 5 sichnia). Osobystyi arkhiv rodyny Sukhomlynskykh. (in Ukrainian)

Sukhomlynskyi, V. (1970 b). Plan roboty Pavlyskoi serednoi shkoly na 1970-1971 navchalnyi rik. [Plan of the Work of Pavlyska Secondary School for the 1970-1971 Academic Year].TsDAVO Ukrainy. Fond 5097. Opys 1. Sprava 930. 108s. (in Ukrainian)

Onyshchenko, O. (2018). Do inkliuzii maie buty hotovym suspilstvo [Society Must Be Ready for Inclusion]. Dzerkalo dushi. No 42-43. URL: https://dt.ua/personalities/doinklyuziyi-maye-buti-gotovim-suspilstvo-293603_html [data zvernennia 26.04.2020]. (in Ukrainian)

Sukhomlinskii, V. (1969). Pavlyshskaia sredniaia shkola. [Pavlysh Secondary School]. Moskva: Prosveshchenie. 400 s. (in Russian)

Sukhomlynskyi, V. (1977). Narodnyi uchytel. Vybrani tvory. V 5 tomakh. [National Teacher. Selected Works]. T.5. Kyiv: Rad. shkola. S.251. (in Ukrainian)

Hartmann, E. (2010). V. O. Sukhomlynskyi: krytyk radianskoi ta kapitalistychnoi systemy: novyi pohliad na spadshchynu klasyka pedahohiky. Shliakh osvity. [V.O. Sukhomlynskyi: a Critic of the Soviet and Capitalist System: A New Look at the Heritage of the Classic of Pedagogy]. No1. S.32-37. (in Russian)

Sukhomlinskii, V. (1988 a). K voprosu ob organizatsii shkol-internatov [On the Question of the Organization of Boarding Schools] (written on August 17, 1956). (napysano 17 serpnia 1956 r.). Sov. pedagogika. No 12. S.82-88. (in Russian)

Sukhomlinskii, V. (1988 b). Pismo N.S. Khrushchevu [Letter to N.S. Khrushchev] [z pryvodu pytan, pidniatykh N.S. Khrushchovym u Dopovidnii zapystsi do Prezydii TsK KPRS, shchodo reformuvannia systemy osvity v SRSR, napisane i vidpravlene 12 chervnia 1959 r.]. Sov. pedagogika. No 3. S. 97-102. (in Russian) 


\title{
VASYL SUKHOMLYNSKYI IN MODERN TIMES: SOME COMMENTS ON THE CONSIDERATION OF IDEAS
}

\author{
Olha Sukhomlynska \\ Doctor of Sciences (in Pedagogy), Professor, \\ Full Member of the NAPS of Ukraine, Chief Researcher, \\ Sukhomlynskyi State National Pedagogical Library, \\ Kyiv, Ukraine \\ ORCID: 0000-0002-2033-285X \\ e-mail:2991946@gmail.com
}

\begin{abstract}
The article presents a view of Vasyl Sukhomlynskyi's herritage from the point of two views: as a historical heritage, giving priority to primary sources, rather than interpretive works, censored texts or collections of excerpts from works, but not interpretive works, censored texts or collections of excerpts from works, as well as a heritage that can still nurture educational practice. An insufficient or superficial study of the source base has been revealed, it is often replaced by works that were published after the death of the author with edited corrections. The article characterizes and reveals those areas of his creative works that have a relevant significance, but have not found appropriate disclosure in both historical and pedagogical research and in generic pedagogical issues.

The author relates to them: the need for a combination, and not separation of theory and practice, both from scientists and teachers; the teacher's thoughts on the organization and carrying out of search and experimental work at school as long-term and balanced process - from the preparatory stage to the unusual long experimentation; the teacher's opinion about the direct participation of students in the organization of their own school environment and space; views of the teacher on the organization and conduct of individual work with difficult children (inclusion); analysis of his thoughts on the "humanization" of knowledge; the importance of emotional and value support of worldviews of education, etc. The chosen approach expands our understanding of the teacher's heritage, and the issues raised in the article enrich and deepen the awareness of those radical changes, that are happening nowadays in Ukrainian education, which are caused, among other things, by historical factors and preconditions.
\end{abstract}

Keywords: Vasyl Sukhomlynskyi, teacher, heritage, relevance, school, education, experimentation, leadership, children, humanism, inclusion, environment, development, ideas, reform.

Стаття надійшла до редакиії 05. 05. 2020 р. 